\title{
Molecular Species Compositions of Intramuscular Triacylglycerols of Beef
}

\author{
Makoto ITOH, Keizou ARIHARA \\ and Yo KONDO \\ School of Veterinary Medicine and Animal Science, \\ Kitasato University, Towada-shi 034
}

(Received April 16, 1997)

\begin{abstract}
The molecular species compositions of triacylglycerols isolated from M. longissimus thoracis of fattened beef cattle (Japanese Black, Japanese Shorthorn, and Holstein steers) were determined by gas chromatography. There were twenty-five molecular species in triacylglycerols. Major species having more than $10 \%$ of total molecular species for at least one breed were palmitoyl (P)-P-oleoyl (O)-glycerol (PPO), P-P-linoleoyl (L)-glycerol (PPL), P-stearoyl (S)-O-glycerol and $\mathrm{P}-\mathrm{O}-\mathrm{O}-$ glycerol (POO). The concentration of $\mathrm{POO}$ was the highest in these species. The concentration of $\mathrm{POO}$ in triacylglycerol was closely associated with the concentrations of PPO and POL.
\end{abstract}

Anim. Sci. Technol. (Jpn.) 68 (8) : 756-759, 1997

Key words : Triacylglycerol, Molecular species, Intramuscular fat, Beef

The quantity and composition of lipid in depot fat of meat are regarded as important factors influencing meat and carcass quality ${ }^{2,3,8,10,12,13)}$. The characteristics of triacylglycerol, being the major component of intramuscular fat of beef, affect the flavor of beef ${ }^{9)}$. Determinations of fatty acid compositions $^{2,4-7)}$, carbon number distributions ${ }^{57}$ and stereospecific position of acyl groups ${ }^{4,5)}$ of triacylglycerol from fat had been carried out for the analysis of chemical characteristics of triacylglycerol, while there were few reports on the molecular species compositions of triacylglycerols isolated from muscle of Japanese beef cattle. In the present paper, we describe the molecular species compositions of triacylglycerols isolated from muscles of three fattened Japanese beef cattle breeds.

\section{Materials and Methods}

$M$. longissimus thoracis at between the tenth and the eleventh rib of carcasses, maintaining 24 to $30 \mathrm{~h}$ at $2^{\circ} \mathrm{C}$ after slaughter, of fattened Japanese Black ( $n=10$ ), Japanese Shorthorn ( $n$ $=10)$ and Holstein $(n=30)$ steers were used for the determination of molecular species compo. sitions of triacylglycerols. The details of fattening conditions for these steers were unknown.

Total lipics in samples were extracted by

ウシ筋肉中のトリアシルグリセロールの分子種組成：伊藤 良・有原圭三・近藤 洋 (北里大学獣医畜産学部, 十 和田市 034) 
chroloform-methanol ${ }^{1)}$. Separation of triacylglycerol from total lipid was carried out by thin layer chromatography using Silica gel $60 \mathrm{H}$ and hexan-diethylether-acetic acid $(80: 30: 1)$ system for development. Molecular species compositions of triacylglycerols were analyzed by gas chromatography using the Ultra Alloy ${ }^{+}$ -65 column ( $15 \mathrm{~m} \times 0.25 \mathrm{~mm}$, Frontier Lab) (unpublished). Identification of the molecular species on the chromatogram was carried out by the comparison with the retention times of the standard triacylglycerols (SIGMA TRI-5, SIGMA TRI-10, SIGMA TRI-19 and the purified sesame oil).

\section{Results and Discussion}

Twenty-five peaks were observed on the gas chromatogram of molecular species of triacylglycerol. The molecular species compositions of triacylglycerols for three breeds are shown in Table 1. Only molecular species present at $>1.0 \%$ for one breed are shown.

The major molecular species were myristoyl (M)-palmitoyl (P)-oleoyl (O)-glycerol (MPO), PPO, P-P-linoleoyl (L)-glycerol (PPL), Pstearoyl (S)-O-glycerol (PSO), POO and SOL. Molecular species having more than $10 \%$ of total molecular species for at least one breed were PPO, PPL, PSO and POO. POO had the highest level in these species of three breeds. Japanese Shorthorn steer had higher concentration of PSO, and lower concentrations of palmitoleoyl (Po)-Po-Po-glycerol (PoPoPo), PPL and P-heptadecanoyl (H)-L-glycerol (PHL) than those of Japanese Black and Holstein steers. From the analysis of the fatty

Table 1. Molecular species compositions of intramuscular triacylglycerols of Japanese Black, Japanese Shorthorn and Holstein steers (Only molecular species present at $>1 \%$ of total molecular species for one breed are shown)

\begin{tabular}{|c|c|c|c|}
\hline Species & $\begin{array}{c}\text { Japanese Black } \\
n=10\end{array}$ & $\begin{array}{l}\text { Japanese Shorthorn } \\
\mathrm{n}=10\end{array}$ & $\begin{array}{c}\text { Holstein } \\
n=30\end{array}$ \\
\hline$M M P^{1)}$ & $2.19(1.41)^{3)}$ & $2.11(1.88)$ & $2.40(1.09)$ \\
\hline$[\mathrm{MPPO}]^{2 \nmid}$ & $2.14(1.89)$ & $1.66(1.56)$ & $2.30(1.44)$ \\
\hline [MPS] & 3. $73(1.44)$ & $4.17(2.20)$ & $3.86(1.08)$ \\
\hline$[\mathrm{MPO}]$ & $9.78(2.48)$ & $8.05(3.70)$ & $9.51(2.32)$ \\
\hline [PoPoPo] & $3.66(1.75)^{\mathrm{ab}}$ & $2.61(1.31)^{\mathrm{a}}$ & $4.14(1.42)^{b}$ \\
\hline MSS & $3.23(0.71)$ & $3.50(1.25)$ & $2.79(0.79)$ \\
\hline $\mathrm{PPO}$ & 15. $26(1.31)$ & 14. $80(3.15)$ & 15. $23(1.36)$ \\
\hline PPL & $9.87(1.54)^{2}$ & $8.04(1.75)^{b}$ & $10.07(1.08)^{\circ}$ \\
\hline$[\mathrm{PHL}]$ & $2.07(0.34)^{a}$ & $1.24(0.51)^{b}$ & 2. $12(0.42)^{a}$ \\
\hline PSO & $10.07(3.11)^{2 b}$ & $12.87(4.04)^{3}$ & $8.06(2.39)^{b}$ \\
\hline $\mathrm{POO}$ & $26.95(4.99)$ & $25.72(5.31)$ & $23.92(4.42)$ \\
\hline POL & $2.01(1.22)$ & $2.24(1.15)$ & $2.79(1.06)$ \\
\hline SOL & $3.25(1.10)$ & $5.52(2.88)$ & $3.23(1.36)$ \\
\hline 000 & $1.92(1.48)$ & 2. $54(2.19)$ & $1.52(1.37)$ \\
\hline $\mathrm{C} 50^{4)}$ & $28.37(1.49)$ & 26. $34(5.39)$ & $27.80(2.17)$ \\
\hline$C 52^{5)}$ & $39.03(5.70)$ & $40.84(8.78)$ & $35.47(5.85)$ \\
\hline $\mathrm{C} 50 / \mathrm{C} 52$ & $0.75(0.16)$ & $0.65(0.29)$ & $0.82(0.22)$ \\
\hline
\end{tabular}

1) $\mathrm{M}$ : myristoyl, $\mathrm{P}$ : palmitoyl, $\mathrm{Po}:$ palmitoleoyl, $\mathrm{H}$ : heptadecanoyl, $\mathrm{S}:$ stearoyl, $\mathrm{O}$ : oleoyl, $L$ : linoleoyl ${ }^{2)}$ presumed species ${ }^{3)}$ mean value with standard deviation in bracket ${ }^{4)} \mathrm{MSS}+\mathrm{PPO}+\mathrm{PPL}{ }^{5)} \mathrm{PSO}+\mathrm{POO}+\mathrm{POL}$

$a, b$ : Means in the same row with different superscript letters are significantly different $(\mathrm{P}<0.01)$. 
acid compositions of triacylglycerols, Japanese Shorthorn had higher concentration of stearic acid and lower concentrations of palmitoleic, hexadecanoic and linoleic acids than those of Japanese Black and/or Holstein steers, while there were no significant differences in the concentrations of palmitic and oleic acids among the three breeds (unpublished data). The differences in the concentrations of PSO, PoPoPo, PPL and PHL between Japanese Shorthorn and the other breeds will be caused by the differences in the compositions of the fatty acids acylated to the glycerol molecules. Tsuneishi et $a l^{7)}$, in determining the relationships between carbon number distribution and double bond number in triacylglycerol from subcutaneous fat of beef cattle, showed that $\mathrm{C}$ 52 having two double bonds was the most predominant, and $\mathrm{C} 50 \mathrm{~s}$ having one double bond and two double bonds were higher than the others. POO (C 52) having 52 carbon number in acyl groups has two double bonds, and PPO (C 50) and PPL (C 50) have one and two double bonds in acyl groups, respectively. The levels of these molecular species in the present study supported the results of Tsuneishi et al.7). Suyama et $a l^{5.6)}$ suggested that the $\mathrm{C} 52$ concentrations in carbon number distributions of triacylglycerols and C 50/C 52 values were different among breeds. In the present study, there were no differences in the $\mathrm{C} 52$ concentrations and C 50/C52 values of triacylglycerol among the three breeds. These differences in various findings are likely to be caused by the difference in the analytical method, differences in the compositions of feeds, or differences in the enzyme activities for fatty acid and triacylglycerol syntheses.

The relationships between $\mathrm{POO}$ and PPO, and $\mathrm{POO}$ and POL concentrations in intramuscular triacylglycerols of three breeds are shown in Fig. 1.

The distribution areas of each relationship for three breeds were not separate individually. There were negative relationship $(\mathrm{P}<0.01)$ between $\mathrm{POO}$ and $\mathrm{PPO}$, and positive relationship
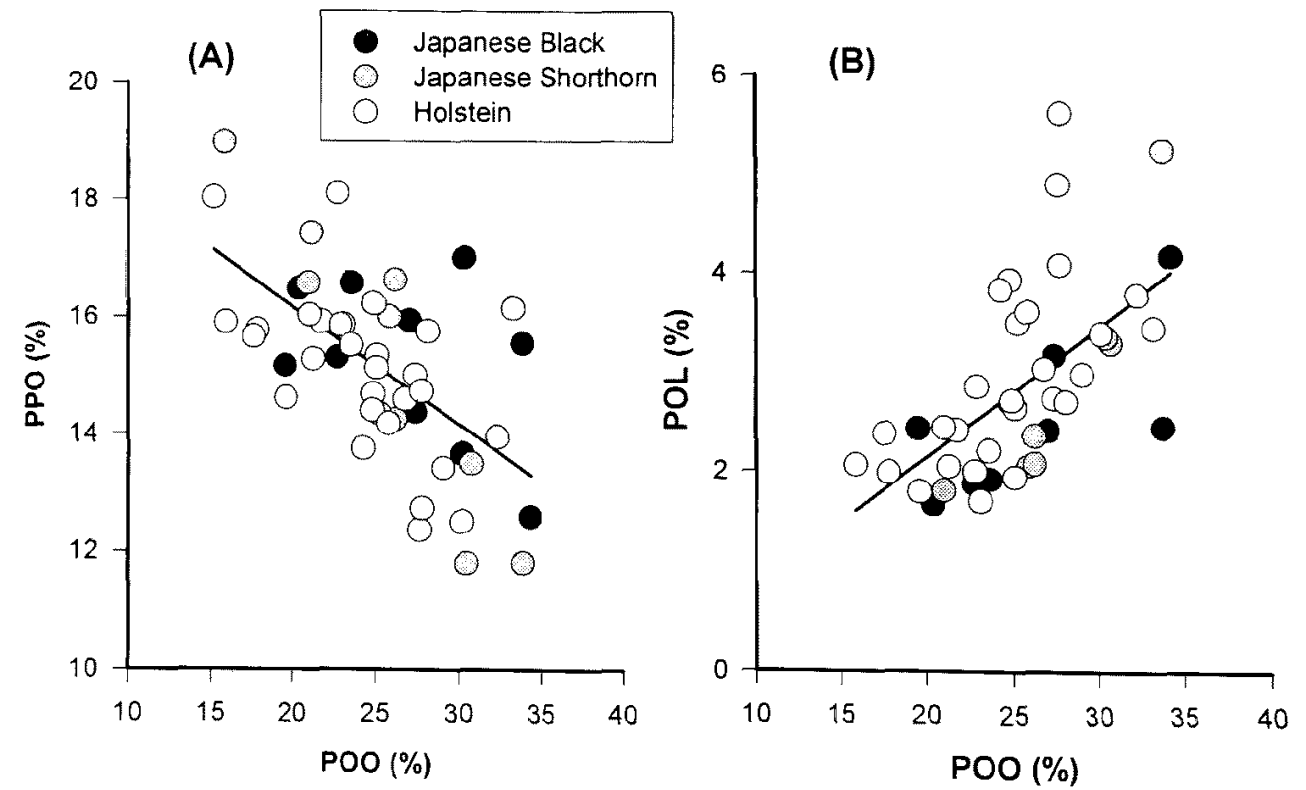

Fig. 1. The ralationships between $\mathrm{POO}$ and $\mathrm{PPO}(\mathrm{A})$, and $\mathrm{POO}$ and POL (B) concentrations in triacylglycerols from $M$. longissimus thoracis of Japanese Black, Japanese Shorthorn and Holstein steers. 
$(\mathrm{P}<0.01)$ between $\mathrm{POO}$ and $\mathrm{POL}$. The values of $\mathrm{PPO} / \mathrm{POO}$ and $\mathrm{POL} / \mathrm{POO}$ were 0.59 ( $\mathrm{SD}=$ $0.14)$ and $0.10(\mathrm{SD}=0.02)$ for Japanese Black, 0.62 $(S D=0.26)$ and $0.10 \quad(S D=0.04)$ for Japanese Shorthorn, and $0.64(\mathrm{SD}=0.17)$ and $0.11(\mathrm{SD}=$ 0.04) for Holstein steers, respectively. There were no significant differences in both values among three breeds. These results suggested that the relationships between $\mathrm{POO}$ and $\mathrm{PPO}$ concentrations, and POO and POL concentrations are common in three breeds. The concentration of linoleic acid (L), being essential fatty acid that have to take from feed, for synthesis of depot triacylglycerol may affect the POO concentration, and the POO concentration may influence the PPO concentration. The concentration of $\mathrm{POO}$ having the highest level in molecular species of triacylglycerol will be closely associated with at least the concentrations of PPO and POL at synthetic stages of triacylglycerol molecules for depot fat. There were no clear relationships between the other molecular species. Further studies with the determination of stereospecifical positions of acyl groups in each molecular species of triacylglycerol are necessary to confirm these relationships.

\section{References}

1) Folch J, Lees M, Saloane-Stanley GH. A simple method for the isolation and purification of tota1 lipids from animal tissues. J. Biol. Chem., 226: 497-509. 1957.

2) Itoh M, Arihara K, Kondo Y. Associations between meat quality evaluation on carcass grading and fatty acid composition in muscle lipid of fattening Holstein steers. Anim. Sci. Technol. (Jpn.), 65 : 368-375. 1994.

3) May SG, Sturdivant CA, Lunt DK, Miller RK, Smith SB. Comparison of sensory characteristics and fatty acid composition between
Wagyu crossbred and Angus steers. Meat Sci., 35: 289-298. 1993.

4) Miller $G$ J, Masor $M$ L, Riley $M$ L. Intramuscular lipids and triglyceride structures in range and feedlot steers. J. Food Sci., 46: 1333-1335. 1981.

5) Suyama K, Adachi S, Tsuchida J, Kamata Y. Dambara H. Fatty acid composition and molecular distribution of triglyceride isolated from depot fats of Japanese Short Horn steers. Jpn. J. Zootech. Sci., 55: 747-754. 1984.

6) Suyama K, Yamaji A, Kutida K, Adachi S, Mizuma Y. Fatty acid composition and molecular distribution of triacylglycerol isolated depot fat of crossbred steers of Brahman Sire $\times$ Japanese Black, Japanese Shorthorn and Holstein dams. Jpn. J. Zootech. Sci., 61 : 10771083. 1990.

7) Tsuneishi E, Watanabe A, Takimoto $Y$. The relation between fatty acid composition and molecular distribution of triacylglycerol isolated from depot fats in beef cattle. Anirn. Sci. Technol. (Jpn.), 65 : 128-134. 1994.

8) Waldman RC, Suess GG, Brungardt V. Fatty acids of certain bovine tissues and their association with growth, carcass and palatability traits. J. Anim. Sci., 27 : 632-635. 1968.

9) Watanabe K, Sato Y. Meat Flavor. Jpn. J. Zootech., Sci. 45:113-128. 1974.

10) Wesserman AE, Talley F. Organoleptic identification of roasted beef, veel, lamb and pork as affected by fat. J. Food Sci., $33: 219-223.1967$.

11) Westerling DB, Hedrick HB. Fatty acid composition of bovine lipids as influenced by diet, sex and anatomical location and relationship to sensory characteristics. T. Anim. Sci., 48 : 1343-1348. 1979.

12) Yoshirsura T, Namikawa K. Influence of breed, sex and anatomical location on lipid and fatty acid composition of bovine intermuscular fat. Jpn. J. Zootech. Sci., 56 : 122-129. 1987.

13) Yoshimura $T$, Namikawa K. Influence of breed, sex and anatomical location on lipid and fatty acid composition of bovine body-cavity fat. Jpn. J. Zootech. Sci., 56 : 130-136. 1987. 